\title{
Changing Landscapes Forest: Implications for its Conservation
}

\author{
James Rodríguez-Echeverry ${ }^{1}$, Rodrigo Fuentes ${ }^{2}$, Margareth Leiton ${ }^{1} \&$ Edilia Jaque ${ }^{3}$ \\ ${ }^{1}$ Facultad de Ingeniería en Ciencias Agropecuarias y Ambientales, Universidad Técnica del Norte, Ecuador \\ ${ }^{2}$ Facultad de Ciencias Forestales, Universidad de Concepción, Chile \\ ${ }^{3}$ Facultad de Arquitectura Urbanismo y Geografía, Universidad de Concepción, Chile \\ Correspondence: James Rodríguez-Echeverry, Facultad de Ingeniería en Ciencias Agropecuarias y Ambientales, \\ Universidad Técnica del Norte, Ecuador. E-mail: wairajames@yahoo.com
}

Received: June 15, 2018

doi:10.5539/enrr.v8n3p44
Accepted: July 2, 2018

Online Published: July 9, 2018

URL: https://doi.org/10.5539/enrr.v8n3p44

\begin{abstract}
The forest landscape of southern Chile, which includes Chilean temperate forest ecosystem, has been designated as a hotspot for biodiversity conservation. However, this landscape has been transformed by land-use change. A proper knowledge about how land-use change impact this ecosystem would provide crucial information for planning conservation strategies. At the commune of Arauco - Chile, the impact of the land-use change on the spatial pattern of native forest ecosystem from 1990 to 2010 was evaluated at the landscape level. This evaluation was carried out using satellite images, landscape metrics and spatially explicit models. The loss of native forest ecosystem was of $40.7 \%$ (loss rate of $4.39 \%$ per year). Conversely, the exotic species plantations increased more than $150 \%$. The number patches of native forest ecosystem increased more than $130 \%$. The size distribution of patches $(<100 \mathrm{ha})$ increased more than $22 \%$. The aggregation index of native forest ecosystem decreased from 62.5 to 40.1 . The loss of native forest ecosystem was caused by the expansion of exotic species plantations, which was associated with substantial changes in the spatial pattern of the forest landscape. As a strategy for conservation of the native forest ecosystem we suggest a landscape approach, using the corridorpatch-matrix model. We recommend that this strategy be complemented with land-use planning. Moreover, this strategy must be supported by a framework of environmental policies. We also recommend strengthening the existing ecological restoration programmes and developing new programmes to restore the native forest ecosystem.
\end{abstract}

Keywords: Deforestation, forest fragmentation, changing landscapes, landscape index, temperate forest.

\section{Introduction}

Land-use change (LUC) can lead to habitat loss and fragmentation, and these are two of the greatest impacts to forest ecosystems (Rodríguez-Echeverry, Echeverría, \& Nahuelhual, 2015). This change have negative effects on the biodiversity and suitable habitat (Díaz, Fargione, Stuart, \& David, 2006), and the composition and spatial configuration of the forest ecosystems (Rodríguez-Echeverry, Echeverría, Oyarzún, \& Morales, 2018). Also, population dynamics and species richness are modified (Watson, Whittaker, \& Dawson, 2004), and ecosystem services, which provide human well-being (Millenium Ecosystem Assessment, 2005), are affected (Aguayo , Pauchard, Azoca, \& Parra, 2009).

Several researchers agree on the need for further research to evaluate fragmentation and deforestation in relation to LUC, in order to generate information that is necessary for land use planning, ecosystem management (Graf, Mathys, \& Bollmann, 2009; Monaghan \& Soares, 2010), and for biological conservation practices (Bao, Zheng, $\&$ Ge, 2006; Simonetti, 2011).

The multitemporal assessment of forest changes related to the analysis of fragmentation and deforestation, based on satellite images and landscape metrics, is a valuable technique to know the degree of threat of an ecosystem (Armenteras, Gast, \& Villarreal, 2003). Most studies based on satellite data have been conducted in tropical forests (Imbernon, \& Branthome, 2001; Sarder, Hepinstall, Coan, \& Soza, 2001; Skole \& Tucker, 1993; Steininger et al., 2001; Turner \& Corlett, 1996), particularly in the Amazon rainforest, which is considered the largest study region in the world (Laurance, 1999; Laurance, Vasconcelos, \& Lovejoy, 2000; Pedlowski, Dale, Matricardi, \& Pereira Da Silva, 1997; Sierra, 2000). This contrasts with the few studies of fragmentation and 
deforestation of temperate forests, particularly in the southern hemisphere (Staus, Strittholt, Dellasala, \& Robinson, 2002).

On the other hand, several studies have used landscape metrics to evaluate the impacts of LUC on the spatial configuration of the landscape (Schulz, Cayuela, Echeverría, Salas, \& Rey-Benayas, 2010) and the impacts of these on ecological processes (León-Muñoz et al., 2013). In this context, it is necessary to evaluate fragmentation and deforestation, in order to generate information that is necessary for land use planning, forest ecosystem management (Monaghan, \& Soares, 2010). This type of research must be supported in the multitemporal assessment of forest changes.

The temperate forest of Chile is considered a "hostpot" of biodiversity conservation (Myers, Mittermeler, Mittermeler, Da Fonseca, \& Kent, 2000). This forest has registered deforestation and fragmentation processes, which have been progressive over the last decades (Echeverría, Newton, Nahuelhual, Coomes, \& Rey-Benayas, 2012; Rodríguez-Echeverry, Echeverría, Oyarzún, \& Morales, 2018). Several studies have reported the direct consequences of LUC in the structure and composition of forest ecosystems (Echeverría, Newton, Lara, Rey-Benayas, \& Coomes, 2007), hydric regime (Little, Lara, Mcphee, \& Urrutia, 2009; Rodríguez-Echeverry, Echeverría, Oyarzún, \& Morales, 2017), increases in erosion and degradation of the soil (Rodríguez-Echeverry, Echeverría, Oyarzún, \& Morales, 2017), and diversity and richness of the fauna and flora (Rodríguez-Echeverry, Echeverría, \& Nahuelhual, 2015; Simonetti, 2011).

Arauco commune, in the Biobio Region of Chile, is a landscape characterized by a high biodiversity, progressive anthropization (DGA, 2004; Corporación Nacional Forestal de Chile [CONAF], 2006) and a high conservation priority (Myers, Mittermeler, Mittermeler, Da Fonseca, \& Kent, 2000). Since the promulgation of Legislative Decree No. 741 of 1974, which encouraged the planting of commercial species in the country, the Arauco commune has exhibited a growing conversion of native forest habitat to commercial plantations (CONAF, 2006). In recent years, it has been reported that various impacts derived from the forest industry have led to a significant loss of wildlife (CONAF, 2006) and a significant increase in the export of sediment in different affluents of the watershed (Oyarzún, Frene, Lacrampe, Huber, \& Herve, 2011). The foregoing has been the focus of discussion among governmental environmental entities, forestry companies, and the general community; all have highlighted the need to implement effective conservation strategies (CONAF, 2006). Currently, no studies have been conducted that quantified the impact of land-use change on the spatial patterns of the temperate forest. This type of study would provide key information for the conservation planning of the native forest at the landscape level.

We assessed the impact of LUC on the spatial pattern Chilean temperate forest ecosystem in the commune of Arauco, Biobío Region-Chile. In particular, we examined the patterns of land-cover change and the changes in the spatial configuration in the temperate forest over time and space by using satellite scenes acquired at different time intervals. We hypothesize that human-induced LUC has substantially fragmented and deforested the forest ecosystem. This work will be the first step to understand the potential ecological effects of fragmentation and the proximate drivers and causes of deforestation.

\section{Study Area}

The commune of Arauco $\left(37^{\circ} 14^{\prime} \mathrm{S}\right.$ and $\left.73^{\circ} 10^{\prime} \mathrm{W}\right)$ is located in the north end of the province of Arauco, on the western slope of the Cordillera de Nahuelbuta (Biobío Region - Chile) (Figure 1). It has an area of $956 \mathrm{~km}^{2}$. Climate data indicates that this zone is characterized by a temperate sub-Antarctic oceanic climate, with an average annual temperature of $14.5^{\circ} \mathrm{C}$ and annual rainfall of $1,350 \mathrm{~mm}$.

\section{Methods}

\subsection{Satellite Images}

LUC and spatial patterns analyses were performed on maps of land use, with $30 \times 30 \mathrm{~m}$ pixels, derived from Landsat satellite images that were recorded in February of the years 1990 (Thematic Mapper, TM) and 2010 (TM). Only maps of 1990 and 2010 were using due to the availability of information, which was bought in the Instituto Militar de Chile. The resolution of these images makes it possible to detect forest patches, which is essential in the analysis and description of the fragmentation processes (Echeverría et al., 2006).

\subsection{Pre-Processing of Images}

A geometric, atmospheric and a topographic correction were applied to each image before classifying them. The geometric correction was performed by Arcgis 9.3 (Esri, 2009) by using a georreference from ground control points and by employing a mathematical model of the third order. The accuracy of this correction ranged from 0.09 to 0.19 pixels, that is to say, 2.7 to 5.7 meters. The Apparent Reflectance Model was employed with the aim 
of transforming the original values of the image into reflectance values (Chávez, 1996). The atmospheric correction was performed using the Envi software, version 4.2. Finally, the topographic correction, which is designed to eliminate shadows in the image produced by the topography of the site (Chuvieco, 2002), was performed by the correction method proposed by Teillet, Guindon, and Goodeonugh (1982).

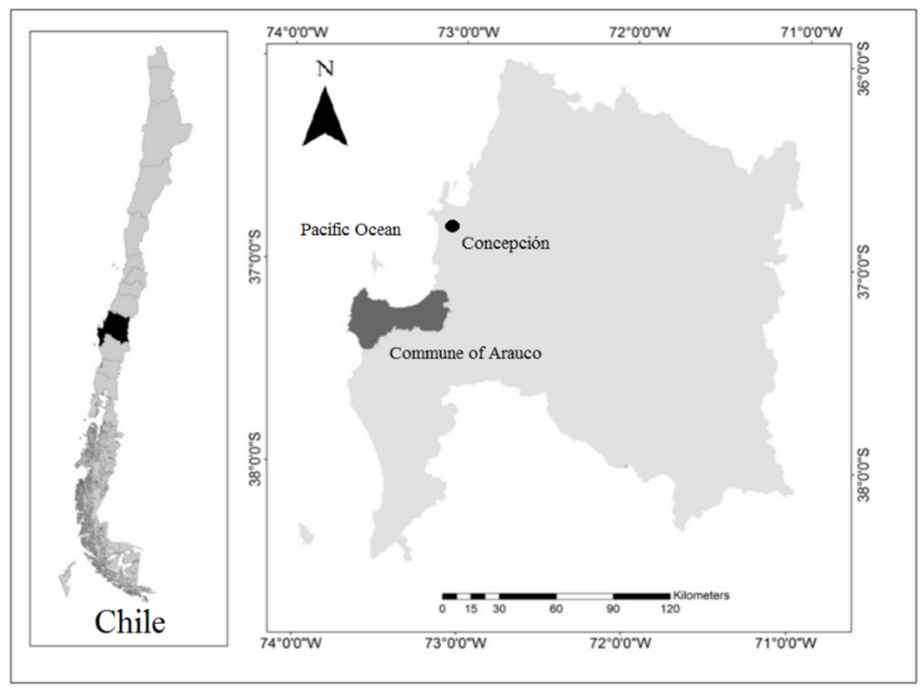

Figure 1. Location of the area of study in the commune of Arauco

\subsection{Image Classification}

The classification of the images was performed using the Envi software, version 4.2, through the selection of training points, following the digital number (DN) of the pixels present (spectral values), and the composition of colours which facilitates the location of each coverage (Chuvieco, 2002).

The classification method was supervised, that is to say, prior knowledge of the study area allows the user to identify representative land uses. This classification was done by using a maximum likelihood algorithm, in which the software identifies and calculates each land uses from the DN that defines each of the classes. Following the classification, each land use was assigned to the remaining pixels of the image, depending on their DN (Parimbelli, 2005). The probability of finding each land use is calculated from the training points selected by the user. The classification of the images was performed using the three spectral bands.

Validation of the 2010 classification was carried out by two different processes: 1) field visits to validate 250 GPS control points for the all cover, and 2) through the choice of 110 random points displayed on the classified image, which was validated by identifying those points in Google Earth. The classification for 1990 was validated using aerial photographs of the land, in addition to "catastro" data of the native forest, reference map on a 1:50000 scale, made from the aerial photographs and satellite images from 1994 and 1997 (CONAF et al., 1999; Echeverría et al., 2006; Echeverría, Newton, Nahuelhual, Coomes, \& Rey-Benayas, 2012). With these elements, confusion matrices were designed to assess the accuracy $(>80 \%)$ between the actual data and the classified maps.

\subsection{Types of Cover}

The following classes of land use cover were identified in each image: 1) Secondary forest (regeneration of pristine forest after disturbance) ,2) crop/grassland (pasture and/or seasonal crops that, due to their spectral response, tend to become confused between them according to the spatial resolution of the classified image), 3) water, 4) urban areas, 5) bare land (represented by harvest plantations areas and dunes), 6) shrubland (vegetal formation where the biological tree type is less than $10 \%$, the shrubland can be between 10 to over $75 \%$ and forbs can be between 0-100\%) (CONAF et al., 1999), and 7) exotic plantations (usually Eucalyptus and Pinus species) and 8) wetlands.

\subsection{Temporal Analysis of Cover Change}

The temporal analysis of cover change was performed through the Land Change Modeler for Ecological Sustainability extension of IDRISI Andes (Clark Labs, Worcester, USA). Land Change Modeler is an extension for the analysis and prediction of change in land cover and evaluation of the consequences of such change on 
biodiversity (Clark-Labs, 2009). This extension provides information on the changes that occurred over a period of time for each class mentioned above, showing the gains and losses of the cover in a clear and precise way. Moreover, it provides maps that help assess the changes over time.

\subsection{Fragmentation Analysis}

The native forest coverage of both years was analysed using Arc Gis 9.3 version, specifically using the Spatial Analyst extension. The analysis of annual deforestation rate that occurred over the duration of the study was calculated by using the formula proposed by FAO (1995), and Echeverría, Newton, Lara, Rey-Benayas and Coomes (2007)

$$
P=\left[\left(\frac{A 2}{A 1}\right)^{\frac{1}{(t 2-t 1)}}-1\right] * 100
$$

Where A1 and A2 are the native forest cover in the $\mathrm{t} 1$ (1990) and $\mathrm{t} 2$ (2010), respectively. P is the percentage of native forest loss per year.

The calculation of indices or landscape metrics and the comparison of these metrics over the duration of this study were performed by using FRAGSTATS software version 3.3 (Echeverría et al., 2006; Mcgarigal, Cushman, Neel, \& Ene, 2002). As such, the changes in the spatial configuration of the landscape were assessed using the landscape indices shown in Table 1.

Table 1. Landscape Indices

\begin{tabular}{ll}
\hline \multicolumn{1}{c}{ Type of Indices } & \multicolumn{1}{c}{ Description } \\
\hline Total area & Surface in ha \\
Largest patch index & $\%$ of landscape composed by the largest patch \\
Density of patches & Number of patches in 100 hectares \\
Number of patches & Number of patches of the corresponding patch type \\
Proximity index & Ratio between the size and proximity of all patches within 500 meters \\
Aggregation index & $\%$ of adjacency between pixels of different kinds of coverage \\
Adjacency index & Length of the edge between secondary forest and the other types of cover in kilometers \\
\hline
\end{tabular}

\section{Results}

\subsection{Accuracy of Classification}

According to the values obtained from both validation processes, accuracies of $86.1 \%$ and $89.4 \%$ for the classification of 1990 and 2010 respectively, were obtained. The accuracy of the type of secondary forest varied from $90 \%$ in 1990 to $84.1 \%$ in 2010 . On the other hand, the various exotic plantation types varied from $87.5 \%$ in 1990 to $92.8 \%$ in the classification of 2010 (Table 2).

Table 2. User accuracy for the classification of images

\begin{tabular}{lcc}
\hline & \multicolumn{2}{c}{ Year } \\
\hline Type of land use & 1990 & 2010 \\
\hline Plantation & 87.5 & 92.8 \\
Urban & 88.2 & 83.3 \\
Crop-grassland & 86.2 & 93.8 \\
Bare land & 90.9 & 95.2 \\
Wetland & 84.0 & 85.7 \\
Water & 82.1 & 100.0 \\
Native & 90.0 & 84.1 \\
Shrubland & 76.7 & 81.0 \\
Total accuracy & 86.11 & 89.44 \\
\hline
\end{tabular}




\subsection{Land Cover Changes}

The changes in the areas of the different types of cover analysed with the land change modeler (Table 3 ), which derives from maps of cover types (Figure 2), indicated that the estimated coverage of secondary forest decreased from 17,932 hectares in 1990 to 7,302 hectares in 2010 . In other words, the native forest cover decreased $40.7 \%$ and it was replaced by exotic plantation. Conversely, the exotic plantation area increased from 25,314 hectares in 1990 to 38,727 hectares in 2010 , which involves more than $150 \%$ of the total area of the study area. As a consequence, the rate of annual deforestation of native forests in these twenty years of study was equivalent to $4.39 \%$ year $^{-1}$.

Table 3. Area of different types of cover for the years 1990 and 2010 in the commune of Arauco

\begin{tabular}{lcccc}
\hline \multirow{2}{*}{ Type of cover } & \multicolumn{2}{c}{ Classification 1990} & \multicolumn{2}{c}{ Classification 2010} \\
\cline { 2 - 5 } & Surface (ha) & $\%$ & Surface (ha) & $\%$ \\
\hline Plantation & $25,314.30$ & 26.4 & $38,727.00$ & 40.4 \\
Bare Soil & $19,931.31$ & 20.7 & $15,459.93$ & 16.1 \\
Water & 357.57 & 0.4 & 397.08 & 0.4 \\
Wetland & $1,933.92$ & 2.0 & $2,426.13$ & 2.5 \\
Secondary forest & $17,932.32$ & 18.7 & $7,302.87$ & 7.4 \\
Crop-grassland & $16,061.13$ & 16.7 & $17,886.69$ & 18.6 \\
Shrubland & $13,782.42$ & 14.4 & $13,034.88$ & 13.6 \\
Urban areas & 665.19 & 0.7 & 743.58 & 0.8 \\
Total & $95,978.16$ & 100 & $95,978.16$ & 100 \\
\hline
\end{tabular}

(A)

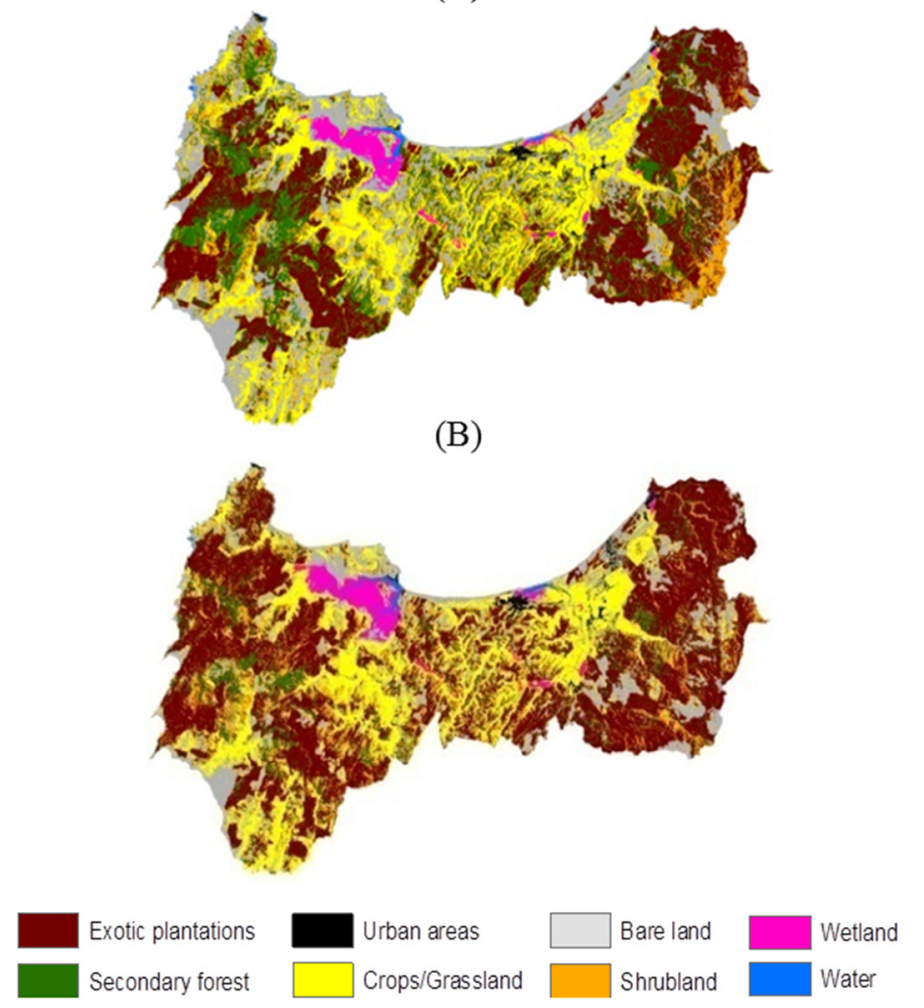

Figure 2. Temporal and spatial variation of the soil covers in the commune of Arauco for (A) 1990 and (B) 2010 


\subsection{Variation in the Size of Patches of Secondary Forest}

One of the main effects of forest fragmentation is the increase in the number of small patches (Figure 3). In the commune of Arauco, there were considerable changes in the size distribution of forest patches between 1990 and 2010 (Figure 3). In 1990, 19\% of the native secondary forest area was concentrated in large patches of between 500 and 2000 ha, $12 \%$ in patches of between 100 and 500 ha and $68 \%$ of the total area of native forest were isolated patches of less than 100 ha. In 2010, about $90 \%$ of the total area of secondary native forest was occupied by very small and isolated forest fragments of less than 100 ha, and only $10 \%$ was occupied by fragments of between 100 and 500 ha.

(A)

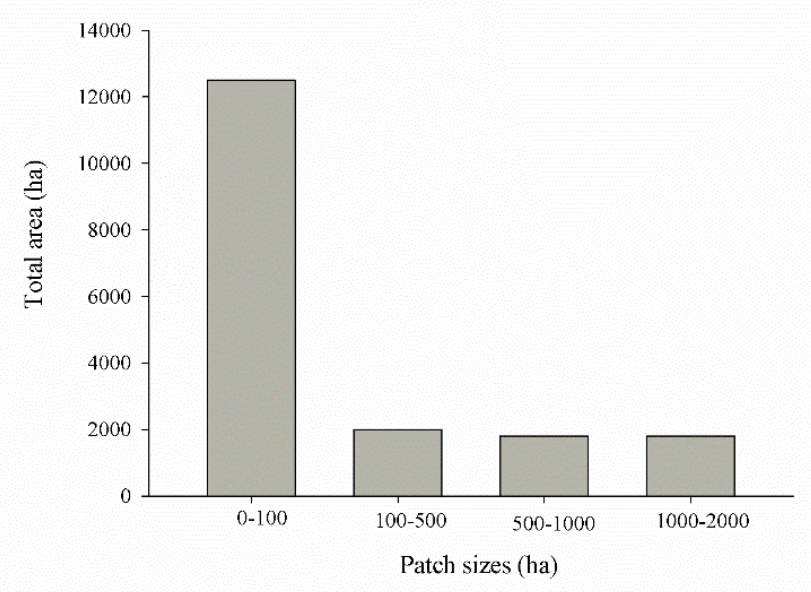

(B)

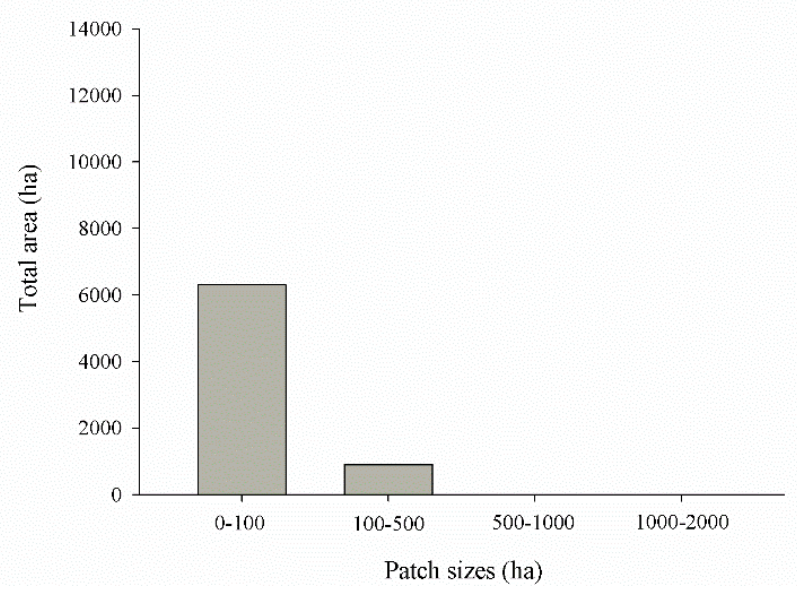

Figure 3. Temporal variation of forest fragment size in the commune of Arauco. A) 1990; B) 2010

\subsection{Spatial Configuration of Native Forest Cover}

Between 1990 and 2010, the area of native forest in the commune of Arauco decreased 56\% (Table 4). During that period, the native forest was mainly affected by constant fragmentation, as evidenced in the increase of the density of patches from 7,46 to 9,79 (Table 4). The proximity index of secondary forest patches consistently decreased from 130.85 to 9.64 between 1990 and 2010 (Table 4). During this period, the patches of forest were spatially separated, as they were occupied by another land cover types. The largest patch index decreased significantly, from 0.79 to 0.12 , over the duration of this study. This decrease coincides with the decrease of the total forest area, which shows the intense and continue processes of fragmentation and deforestation. The mean shape index showed a slight decrease of $0.17 \%$ (Table 4). This demonstrates that the shape had a tendency to be less irregular in isolated patches. Finally, patch density increased from 7.46 to 9.79 patches in 100 hectares during this period. 
Table 4. Changes in the landscape index for native forest in the commune of Arauco between 1990 and 2010

\begin{tabular}{lcc}
\hline \multicolumn{1}{c}{ Landscape Indices } & 1990 & 2010 \\
\hline Total area (ha) & 17932.32 & 7302.87 \\
Largest patch index & 0.79 & 0.13 \\
Density of patches & 7.46 & 9.79 \\
Number of patches & 15780 & 20699 \\
Proximity Index & 130.85 & 9.64 \\
\hline oral Relationship Between Native Forest and other Land Cover Types
\end{tabular}

4.5 Spatial and Temporal Relationship Between Native Forest and other Land Cover Types

In 1990, the exotic plantations, wetlands, crop-grassland, bare land and secondary forest showed a significant aggregation of over $60 \%$ (Figure 4). However, in 2010 all the land uses presented disaggregation, which was more significant in the case of the native forest with $40 \%$, and bare land and crop-grassland between $60 \%$ and $80 \%$. This contrasts with the plantations of exotic species that showed the highest and most significant aggregation of $90 \%$ (Figure 4 ).

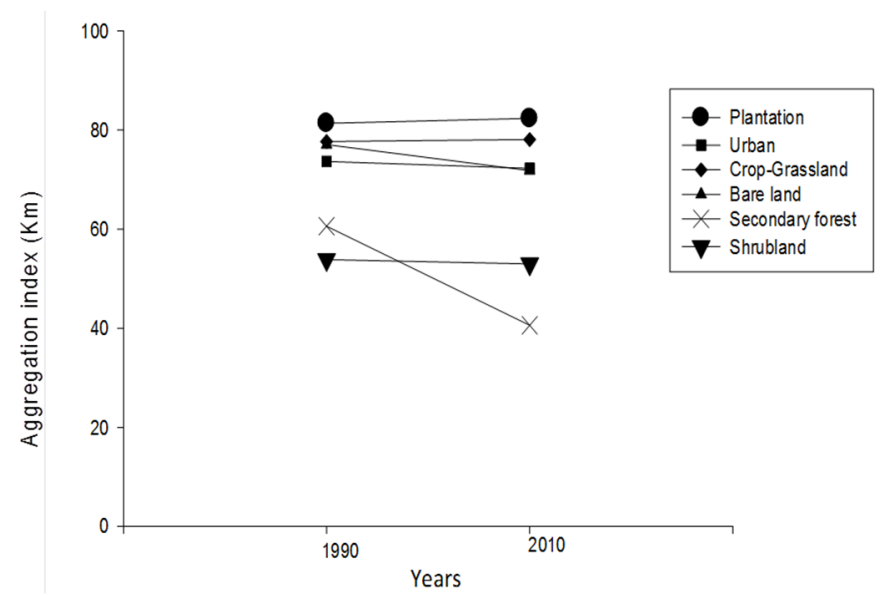

Figure 4. Temporal changes in the aggregation index in the commune of Arauco between 1990 and 2010.

The adjacency index indicates that in 1990 the native forest patches were frequently closer to other land uses, especially to shrubland, with which it shared a length of nearly $110 \mathrm{~km}$. (Figure 5). However, by 2010 this index had decreased for all types of cover except for the plantation type. This decrease indicates that in 20 years the area occupied by exotic plantations has increased, thus increasing its contact with the remnants of native forest in the commune of Arauco.

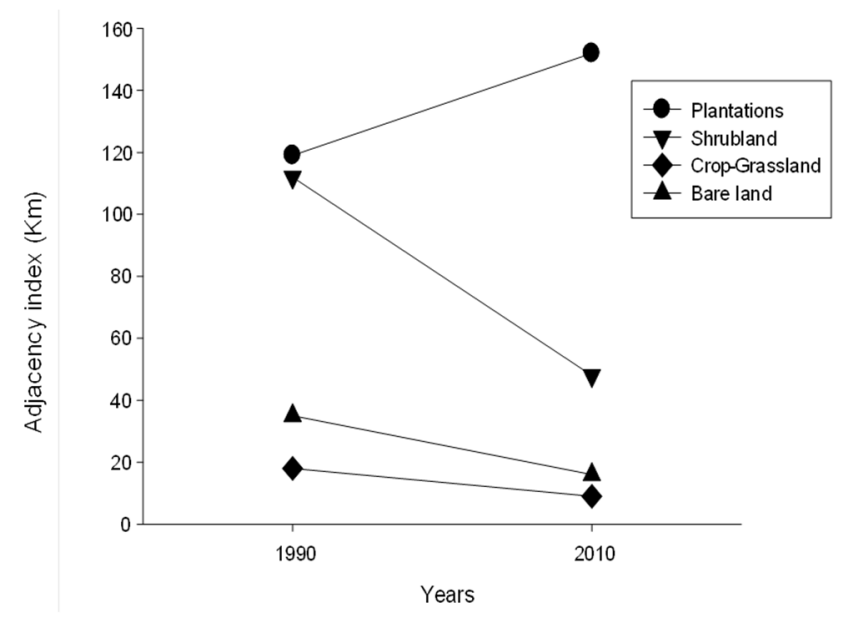

Figure 5. Temporal changes in the adjacency index 


\section{Discussion}

The commune of Arauco has had a high rate of deforestation in the past 20 years, which was mainly due to the growth of exotic plantations (Pinus radiata, Eucalyptus globulus). This deforestation produced a loss close to 10,000 hectares of secondary forest, which corresponds to an annual rate of loss of $4.39 \%$. This loss of native forest is similar to the reported by Echeverría et al. (2006), which, due to the habilitation of land for the plantations of exotic species, reached 4.5\% in temperate forests in the Maule region between 1976 and 2007. On other hand, Schulz, Cayuela, Echeverría, Salas and Rey-Benayas (2010) reported a deforestation rate of $1.7 \%$ in the sclerophyllous forests of central Chile between 1975 and 2008, mainly due to the use of wood as fuel. The number and density of patches of native forest in the commune of Arauco increased significantly between 1990 and 2010. Rodríguez-Echeverry, Echeverría, Oyarzún and Morales (2018) reported a substantial fragmentation of the Valdivian Temperate Forest between 1986 and 2011. Similarly, Cayuela, Rey, Benayas, and Echeverría et al. (2006), showed that the significant increase in the number and density of patches was related to the concentration of native forest in patches of less than 100 ha in the tropical montane forests of Chiapas in Mexico. In the commune of Arauco, in the last two decades, there has been a significant fragmentation of the native secondary forest. This fragmentation was due to an indiscriminate use of land, which does not reflect any appreciation or conservation planning for the native forest as an ecosystem.

In this study, the patch size consistently decreased over time. Therefore, the proximity of native forest patches also recorded a dramatic reduction. According to Armenteras, Gast and Villarreal (2003), the progressive reduction in the size of habitat patches is a key indicator of the ecosystem fragmentation. This reduction in size may decrease the connectivity among habitats, which then reduces or restricts the ecological flow, affecting ecosystem processes and services (Rodríguez-Echeverry, Echeverría, Oyarzún, \& Morales, 2017). Therefore, the forest ecosystem in the commune of Arauco may register a critical condition in relation to the sustainability of the species, processes and ecosystem services.

While the area of exotic plantations registers the highest aggregation indices during the two decades, the area of the forest ecosystem was severely impacted by fragmentation and degradation process. Thus, the exotic species plantations become the type of cover that dominates the landscape study. In addition, the matrix of study area, which is the portion of the landscape that is better connected that controls key ecosystem processes such as water and energy flows (Rodríguez-Echeverry, Echeverría, \& Nahuelhual, 2015), was surrounded mainly by crop-grassland lands and bare soil, which contributes to the intense fragmentation and degradation processes.

The analysis of spatial patterns of landscape index need to be understood as a first step towards understanding ecological processes ( $\mathrm{Li} \& \mathrm{Wu}, 2004)$. However, it is necessary to complement this work with further studies that provide a comprehensive assessment of the impacts of the forest fragmentation and degradation on biodiversity and ecosystem services at the landscape level. These studies could contribute key information to implement measures of conservation.

\subsection{Implications for Conservation}

The current state of the forest ecosystem provides important information for its management, sustainable development and biodiversity conservation. Therefore, the current configuration of the landscape in the study area should be considered as model to help institute urgent conservation and management plans. As a first step in conserving the forest ecosystem, we suggest a landscape approach, using the corridor-patch-matrix model (Lindenmayer \& Franklin, 2002), as a strategy for conservation planning. This is appropriate given the current configuration of the landscape, with native forest restricted to small patches sparsely distributed across the landscape. The main objective of the corridor-patch-matrix model is to maintain the quality and quantity of patches of native forest through management of the matrix (Lindenmayer \& Franklin, 2002). The condition of the matrix may be more important in determining the survival of the species than the isolation of patches (Lindenmayer \& Franklin, 2002). In the study landscape the management of the matrix should focus on sensitive buffer areas that improve the connectivity between forest patches and increase the ability of the matrix. We recommend that this strategy be complemented with land-use planning focused on sustainable production practices such as agroforestry. The design and implementation of such a strategy requires identification and evaluation of sensitive buffer areas and their connectivity. Moreover, this strategy must be supported by a framework of environmental policies. We also recommend strengthening the existing restoration programmes and developing new programmes. 


\section{Conclusion}

The research applies standard remote sensing methods in conjunction with spatial pattern analyses to an area of southern hemisphere temperate forest never previously studied. The analyses conducted illustrated how forest loss was strongly associated with an increase in area of exotic species plantations.

This study has succeeded in quantifying the major changes in forest cover in Arauco commune, and in assessing the substantial forest loss that has taken place over the last decades. In this sense, the fragmentation of the native forest has reduced habitat connectivity and threatens its biodiversity. However, knowing the changes in spatial patterns of forest ecosystem and their current status provides important information for the design, land use planning and landscape management strategies that can promote biodiversity conservation and ecosystem services. This is possible if the situation is approached from a transdisciplinary perspective and if initiatives involve the active participation of the Chilean government and the general community.

The successful description of pattern change accompanying deforestation and forest fragmentation provides a critical component of habitat analysis. These changes may result in the elimination, displacement or enhancement of species populations. Additionally, the identification of these patterns is important to facilitate future landscape management and monitoring actions in this type of forest.

This study reflects the lack of economic alternatives and the community's lack of awareness of their environment, its processes and cycles. This lack of awareness has had environmental consequences that threaten not only the preservation of remnants of the forest ecosystem but also the modification of processes and ecosystem services that provide the well-being of the community. Therefore, it is necessary to development policies that have an ecological background, which focus to revert the degradation of native forests.

\section{Acknowledgements}

We thank Dr. Albert Hernández, Laboratorio de Ecología de Paisaje de la Universidad de Concepción, DIUC FI project 209603010-1. Special thanks for the CONICYT and MECESUP scholarship by Ministry of Education of Chile. We also greatly appreciate the valuable comments we received from anonymous reviewers.

\section{References}

Aguayo, M., Pauchard, A., Azoca, G., \& Parra, O. (2009). Cambio del uso del suelo en el centro sur de Chile a fines del siglo XX: Entendiendo la dinámica espacial y temporal del paisaje. Revista Chilena de Historia Natural, (82), 361-374.

Armenteras, D., Gast, F., \& Villarreal, H. (2003). Andean forest fragmentation and the representativeness of protected natural areas in the eastern Andes, Colombia. Biological Conservation, (113), 245-256.

Bao, Y., Zheng, X., \& Ge, B. (2006) Assessment and protective strategy of black muntjac habitat in Zhejiang, China. Acta Ecológica Sinica, (26), 2425-2431.

Cayuela, L., Rey-Benayas, J. M., \& Echeverría, C. (2006). Clearance and fragmentation of tropical montane forests in the Highlands of Chiapas, Mexico (1975-2000). Forest Ecology and Management, (226), 208-218.

Chavez, P. (1996). Image -based atmospheric corrections. Photogrammetric Engineering and Remote Sensing, (62), 1025- 1036.

Chuvieco, E. (2002). Teledetección ambiental. La observación de la tierra desde el espacio. Primera edición. Barcelona España. Editorial Ariel, S.A.

Clark- Labs. (2009). The Land Change Modeler for Ecological Sustainability. USA: Idrisi Focus Paper.

Corporación Nacional Forestal de Chile [CONAF]. (2006). Plan Integral de Gestión Ambiental del Humedal de Río Cruces. Valdivia Chile. Valdivia: Corporación Nacional Forestal.

Corporación Nacional Forestal de Chile [CONAF], Conama, Birf, Chile U. A. d., Chile P. U. C. d, \& Universidad Católica de Temuco. (1999). Catastro y Evaluación de la Vegetación Nativa de Chile. Manual de cartografia de la vegetación. Santiago de Chile. Corporación Nacional Forestal de Chile

Crow, T. R., \& Gustafson, E. J. (1997). Ecosystem management: Managing natural resource in time and space. In K. A.

Khom, \& J. F. Franklin (Eds.), Creating a forestry for the twenty first century: The science of ecosystem management (pp. 215-228). Washington, D.C.: Island Press. 
Díaz, S., Fargione, J., Stuart, F., \& David T. (2006). Biodiversity Loss Threatens Human Well-Being. PLoS Biology, (4), 1300-1305.

Echeverría, C., Coomes, D. A., Salas, J., Rey-Benayas, J. M., Lara, A., \& Newton A. C. (2006). Rapid deforestation and fragmentation of Chilean temperate forests. Biological Conservation, 130 (4), 481-494.

Echeverría, C., Newton, A. C., Lara, A., Rey-Benayas, J. M., \& Coomes, D. A. (2007). Impacts of forest fragmentation on species composition and forest structure in the temperate landscape of southern Chile. Global Ecology and Biogeography, (16), 426-439.

Echeverría, C., Newton, A. C., Nahuelhual, L., Coomes, D. A., \& Rey-Benayas, J. M. (2012). How landscape change: Integration of spatial patterns and human processes in temperate landscapes of southern Chile. Applied Geography, (32), 822-831.

ESRI. (2009). Environmental Systems Research Institute, Inc. USA, New York: St., Redlands, CA92373-8100.

FAO. (1995). Forest Resources Assessment 1990. Global Synthesis. FAO, Rome, Italy.

Graf, R., Mathys, L., \& Bollmann, K. (2009). Habitat assessment for forest dwelling species using LiDAR remote sensing: Capercaillie in the Alps. Forest Ecology and Management, (257), 160-167.

Imbernon, J., \& Branthomme, A. (2001). Characterization of landscape patterns of deforestation in tropical rain forests. International Journal of Remote Sensing, (22), 1753-1765.

Imbernon, J., Villacorta, J. L., Zelaya, C. L., \& Valle A. A. (2005). Fragmentación y cconectividad del bosque en El Salvador, aplicación al Corredor Biológico Mesoamericano. Bois et Forêts des Tropiques, 286(4), $15-28$.

Laurance, W. F. (1999). Reflections on the tropical deforestation crisis. Biological Conservation, (91), 109-117.

Laurance, W. F., Vasconcelos, H. L., \& Lovejoy, T. E. (2000). Forest loss and fragmentation in the Amazon: implications for wildlife conservation. Oryx, (34), 39-45.

León-Muñoz, J., Echeverría, C., Marcé, R., Riss, W., Sherman, B., \& Iriarte, J. (2013). The combined impact of land use change and aquaculture on sediment and water quality in oligotrophic Lake Rupanco (North Patagonia, Chile, $40.8^{\circ}$ S). Journal of Environmental Management, (128), 283-291.

Li, H., \& Wu, J. (2004). Use and misuse of landscape indices. Landscape Ecology, (19), 389-399.

Lindenmayer, D. B., \& Franklin, J. F. (2002). Conserving forest biodiversity: A comprenhensive multiscaled approach. Washington, DC.: Island Press.

Little, C., Lara, A., Mcphee, J., \& Urrutia, R. (2009). Revealing the impact of forest exotic plantations on water yield in large scale watersheds in South-Central Chile. Journal of Hydrology, (374), 162-170.

Mcgarigal, K., Cushman, S. A., Neel, M. C., \& Ene E. (2002). Fragstats: Spatial Pattern Analysis Program for Categorical Maps. Computer software program produced by the authors at the University of Massachusetts, Amherst. Retrieved from http://www.umass.edu/landeco/research/fragstats/fragstats.html

Millennium Ecosystem Assessment. (2005). Ecosystems and human well-being: Biodiversity synthesis. Washington D.C.: World Resources Institute.

Monaghan, K., \& Soares, A. (2010). The bioassessment of fish and macroinvertebrates in a MediterraneanAtlantic climate: Habitat assessment and concordance between contrasting ecological samples. Ecological Indicators, (10), 184-191.

Myers, N., Mittermeler, R. A., Mittermeler, C. G., Da Fonseca, G. A. B., \& Kent J. (2000). Biodiversity hotspots for conservation priorities. Nature, (403), 853-858.

Noss, R. F. (2001). Forest fragmentation in the southern rocky mountains. Landscape Ecology, (16), 371-372.

Oyarzún, C. E., Frene, C., Lacrampe, G., Huber, A., \& Herve, P. (2011). Propiedades hidrológicas del suelo y exportacioón de sedimentos en dos microcuencas de la Cordillera de la Costa en el sur de Chile con diferente cobertura vegetal. Bosque (32), 10-19.

Parimbelli, M. (2005). Clasificación Supervisada- Multispec ${ }^{R}$. Técnicas espaciales de análisis. Argentina. Universidad CAECE.

Pedlowski, M., Dale, V. H., Matricardi, E. A. T., \& Pereira Da Silva, F. E. (1997). Patterns and impacts of deforestation in Rondoma, Brazil. Landscape and Urban Planning, (38), 149-157. 
Ranta, P., Blom, T., Niemela, J., Joensuu, E., \& Siitonen, M. (1998). The fragmented Atlantic rain forest of Brazil: size, shape and distribution of forest fragments. Biodiversity and Conservation, (7), 385-403.

Rodríguez-Echeverry, J., Echeverría, C., \& Nahuelhual, L. (2015). Impacts of anthropogenic land-use change on populations of the Endangered Patagonian cypress Fitzroya cupressoides in southern Chile: implications for its conservation. Oryx, 49(3), 447-452.

Rodríguez-Echeverry, J., Echeverría, C., Oyarzún, C., \& Morales, L. (2017). Spatial congruence between biodiversity and ecosystem services in a forest landscape in southern Chile: basis for conservation planning. Bosque, 38(3), 495- 507.

Rodríguez-Echeverry, J., Echeverría, C., Oyarzún, C., \& Morales, L. (2018). Impact of land-use change on biodiversity and ecosystem services in the Chilean temperate forests. Landscape Ecology, 33(3), 439-453.

Sarder, S. A., Hepinstall, D. J. H., Coan, M., \& Soza, C. (2001). Forest change monitoring of a remote biosphere reserve. International Journal of Remote Sensing, (22), 1937-1950.

Schulz, J. J., Cayuela, L., Echeverría, C., Salas, J., \& Rey-Benayas J. M. (2010). Monitoring land cover change of the dryland forest landscape of Central Chile (1975-2008). Applied Geography, (30), 436-447.

Sierra, R. (2000). Dynamics and patterns of deforestation in the western Amazon: the Napo deforestation front, 1986-1996. Applied Geography, (20), 1-16.

Skole, D., \& Tucker C. (1993). Tropical deforestation and habitat fragmentation in the Amazon: satellite data from 1978 to 1988. Science, (260), 1905-1909.

Simonetti, J. (2011). Conservation biology in Chile: Are we fulfilling our social contract?. Revista Chilena de Historia Natural, (84), 161-170.

Steininger, M., Tucker, C., Ersts, P., Killeen, T., Villegas, Z., \& Hecht, S. (2001). Clearance and fragmentation of tropical deciduous forest in the Tierras Bajas, Santa Cruz, Bolivia. Conservation Biology, (15), 856-866.

Staus, N., Strittholt, J., Dellasala, D., \& Robinson, R. (2002). Rate and patterns of forest disturbance in the Klamath-Siskiyou ecoregion, USA between 1972 and 1992. Landscape Ecology, (17), 455-470.

Teillet, P., Guindon, B., \& Goodeonugh D.G. (1982). On the Slope-aspect correction of multispectral scanner data. Canadian Journal of Remote Sensing, (8), 84-106.

Turner, I. M., \& Corlett, T. (1996). The conversion value of small, isolated fragments of lowland tropical rain forest. Trends in Ecology \& Evolution, (11), 330-333.

Vagen, T. G. (2006). Remote sensing of complex land use change trajectories- a case study from the highlands of Madagascar. Agriculture Ecosystems \& Environment, (115), 219-228.

Watson, J., Whittaker, R., \& Dawson, T. (2004). Habitat structure and proximity to forest edge affect the abundance and distribution of forest-dependent birds in tropical coastal forest of southern Madagascar. Biological Conservation, (120), 311-327.

\section{Copyrights}

Copyright for this article is retained by the author(s), with first publication rights granted to the journal.

This is an open-access article distributed under the terms and conditions of the Creative Commons Attribution license (http://creativecommons.org/licenses/by/4.0/). 